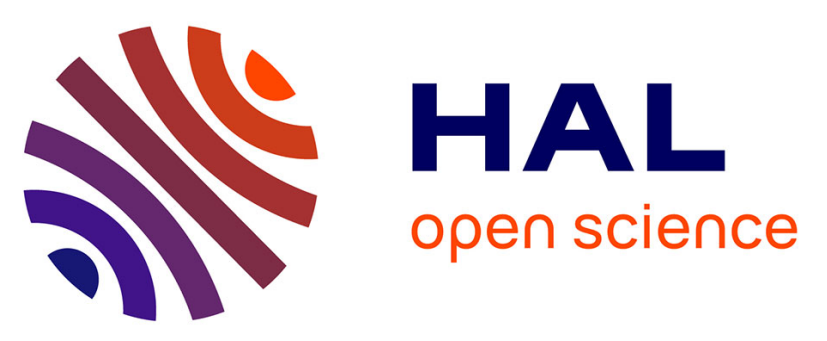

\title{
Communication on Food, Health and Nutrition. A cross-cultural analysis of the Danonino Brand and Nutri-tainment
}

\author{
Malene Gram, Valérie-Inès de La Ville, André Le Roux, Nathalie \\ Boireau-Ducept, Olivier Rampnoux
}

\section{To cite this version:}

Malene Gram, Valérie-Inès de La Ville, André Le Roux, Nathalie Boireau-Ducept, Olivier Rampnoux. Communication on Food, Health and Nutrition. A cross-cultural analysis of the Danonino Brand and Nutri-tainment. Journal of Marketing Communications, 2010, Marketing Communications in the Food Sector, 16 (1-2), pp.87-103. 10.1080/13527260903342803 . hal-01627913

\section{HAL Id: hal-01627913 https://hal.science/hal-01627913}

Submitted on 8 Mar 2019

HAL is a multi-disciplinary open access archive for the deposit and dissemination of scientific research documents, whether they are published or not. The documents may come from teaching and research institutions in France or abroad, or from public or private research centers.
L'archive ouverte pluridisciplinaire HAL, est destinée au dépôt et à la diffusion de documents scientifiques de niveau recherche, publiés ou non, émanant des établissements d'enseignement et de recherche français ou étrangers, des laboratoires publics ou privés. 


\title{
Communication on food, health and nutrition: A cross- cultural analysis of the Danonino brand and nutri-tainment
}

\author{
Malene Gram ${ }^{\mathrm{a}}$, Valérie-Inés de la Ville ${ }^{\mathrm{b}}$, André Le Roux ${ }^{\mathrm{b}}$, Nathalie Boireau ${ }^{\mathrm{c}}$ and Olivier \\ Rampnoux $^{\mathrm{b}}$ \\ ${ }^{a}$ Aalborg University, Fibigerstraede 2, 9220 Aalborg East, Denmark; ${ }^{b}$ University of Poitier, France; \\ ${ }^{c}$ Consumer Science Danone Research, Palaiseau, France
}

\begin{abstract}
The aim of this article is to explore how Danone intertwines the health discourse and the entertainment aspects when promoting their products to parents and children across cultures and in communicating to its global markets. In order to examine Danone's communication strategy in the various cultural contexts, the following will be analysed: who talks about health; how healthy eating is presented; and finally how playful and entertaining aspects of health are enacted in Danone's commercials. In the analysis, focus is on Danone's 'Danonino' brand, how the global market is approached and how it draws on the concept of 'nutri-tainment' (nutrition and entertainment). The sample consists of 175 commercials from six markets (France, Spain, Germany, Russia, Poland, Denmark) aired from 2001 to 2007. The analysis involves a quantitative exploration and clustering analysis of which themes appear in which markets. This differentiates four groups of advertisements: 'Utility'; 'Adventure'; 'Entertainment'; and 'Activity'. It is complemented by a qualitative analysis of typical traits in commercials drawing on an analysis of the person or character that appears to be empowered to talk about health, how healthy eating is communicated and finally what is emphasised as being 'healthy' in the various national contexts.
\end{abstract}

Keywords: food marketing; health advertising on global markets; marketing to children and parents

\section{Introduction}

Culture matters when it comes to food, and food is intimately linked to social contexts and values. The meaning of what is perceived as good and healthy food is not universal, also food is symbolic (Douglas 1984). Especially as regards food for children the symbolism and the values are perhaps even more pronounced, as childhood and perceptions of what is good for children are anchored in cultural contexts. Traditionally children have been considered human becomings (as objects: vulnerable, innocent and incomplete) rather than human beings (as actors: competent and agents in their own right) (Qvortrup 1987). With its range of dairy products directed at children, Danone is acting in the middle of this minefield, appealing to a global audience. The aim of this article is to explore how the communication between Danone and its global markets is handled. The article focuses on how Danone intertwines the health discourse and the entertainment aspects when promoting their products to parents and children across cultures, thus, presenting a detailed case study of how one global company communicates health to a global market. This will give the reader an insight into the webs of meaning at play in Danone's field of

*Corresponding author. Email: gram@ihis.aau.dk 
operation, how health is staged and which actors can talk about health in various cultural contexts.

In order to examine Danone's communication strategy across cultures, the following will be analysed: who talks about health; how healthy eating is presented; and finally how playful and entertaining aspects of health are enacted in Danone's commercials. The analysis focuses on the 'Danonino' brand, how the global market is approached and how it draws on the concept of 'nutri-tainment' (nutrition and entertainment). The sample consists of 175 commercials from six markets. The analysis involves a quantitative exploration of which themes appear in which markets, and a qualitative analysis of typical traits in commercials drawing on health discourse. In this article the authors will not discuss the actual health value of the Danonino products but merely analyse how the products have been promoted in various European countries with regard to health.

\section{Literature review and theoretical considerations}

Sociological studies on food consumption show that food is not just a matter of nutrition, but also of symbols and myths (Douglas 1984; Fischler 1988), which is an important expression of identity (Atkins and Bowler 2001). Income, age, gender and household composition also influence food consumption. A number of dilemmas are identified in relation to food culture: novelty vs tradition; health vs indulgence; convenience vs care; and economy vs extravagance. These dilemmas reflect consumers' and food providers' ongoing struggles (Warde 1997). At the same time, consumer literature has established that the meaning attached to food products and food consumption is all the more important for the post-modern consumer who shifts between different lifestyles and identities, and in so doing draws on consumption patterns (Featherstone 1995; Fuat Firat and Venkatesh 1995). Furthermore food is intimately linked to social relationships (Caplan 2002; James 1982), and even more so where children are involved. A large part of being a modern, particularly western, parent is to shop to provide food for one's children (Seiter 1993). At the same time food is not just any old product, human beings eat to live, the child has to eat well to thrive and food can be an effective means of negotiation in a power struggle (Cook 2007).

In the light of the enormous problems related to obesity and overweight in particular in the western world, healthy eating, especially in relation to children, is now very much finding its way onto the agenda, in research, in public debates and in governance on several levels. Research indicates that consumers in European markets show a growing interest in health and healthy eating campaigns, albeit this interest seems to some extent to remain on the level of good intentions (Rudawska 2001).

Food consumption is an arena with differences in interest and opinion between parents and children. Based on a review of several studies, Russell and Worsley (2007) write that children eat what they like and not what they dislike. Solomon (1996) (see also Turner, James, and McKenna 2006, 184) writes that parents can be influenced and surrender to their children's requests for food that they prefer, or parents can try to resolve a conflict by exercising power. Food advertising seems to exploit this conflict. In a study on food advertising messages aimed at children, messages were found to be linked to fantasy and fun rather than health and nutrition (Hastings et al. 2003; see also Turner et al. 2006, 185). Mintel (2002) (quoted in Turner et al. 2006, 184) writes that there is a tendency to give children treats to compensate guilt and to gain the child's affection. The 'need' versus 'want' conflict thus constitutes a complex hodgepodge of meanings, knowledge, good intentions, wishes to please and to win affection.National culture has been found to play a significant role in food consumption and in the assessment of what can be perceived as 
'good food'. In their study of feeding practices in five European countries, Synnott et al. (2007) found a number of cross-cultural differences. German and Scottish participants find that a 'healthy diet' should be as natural as possible, and German participants believe that organic food ingredients are better for their infants. The Spanish and Italian participants rely on authorities such as paediatricians for information on infant feeding practice $(2007,953)$. A healthy diet is connected with variety and balance in Italy and Spain whereas in Germany, Scotland and Sweden it is almost exclusively associated with fruit and vegetables $(2007,954)$.

Several issues are thus at play when it comes to advertising food products for children in Europe. Four central axes are: (1) the dichotomy of healthy versus unhealthy; (2) whether children like the food or not, and do they eat what the parent serves; (3) whether the child likes/dislikes his or her parents (reflecting parents' desire to be loved by the child); and finally

(4) whether or not the parent feels safe and adequate or guilty and worried. The content of these axes is closely related to culturally bound definitions, and in the following analysis the axes are used as a prism through which the commercials are observed.

\section{Methodology}

Before analysing Danone's approach to the global market for children's foods, the group's global mission and corporate strategy is presented: 'To maintain the Group's long-term competitive advantage, Danone Research is constantly challenged to offer products with meaningful differentiation in terms of health and nutritional benefits, packaging, texture, taste and sensory signature. ${ }^{1}$ The way Danone legitimates its adapting efforts depends on the target (seniors, active adults, children, etc.). Danone's leading children's brand, Danonino, builds its differentiation strategy by developing national nutritional profiles: 'The right nutrients for the right country.'2 The Danone Group claims to have adapted the nutritional content of their Danonino products, commercialised in more than 35 countries, to the specific needs of children in more than 15 countries: in Brazil, where anaemia and malnutrition coexist with obesity, Danonino adds calcium, iron, vitamins D and zinc to the product; in Argentina, iron and zinc. In Europe, the formula is also slightly adapted to meet children's needs: in Spain, France and Poland, with calcium and vitamin D, whereas in Russia iodine is added to the product. By adapting the products' nutrients to local needs, Danone seeks to strengthen the global value of its brand: 'Danonino's goal is to help children optimize their nutritional intake in order to facilitate healthy growth, this after studying the nutritional deficiencies of each country'. ${ }^{3}$ In order to develop an accurate picture of the actual state of children's health in a particular country, Danone initiates collaboration with local medical bodies or scientific institutes - like for instance the Institute for Mothers and Children in Poland - and launches nationwide studies on children's nutrition and on physical effects of nutrition on children's growth. This networking strategy is an attempt to increase Danone's legitimacy to adapt the formula of the Danonino products.

To a large extent Danone's commercials directed at children are standardised often using the same cartoons starring the brand character Danonino, a small dragon. The approach in commercials directed at parents (mothers) is differentiated and anchored in the local context even though the same idea is often seen in several countries (for example a concept with a teacher or a parent recommending the product, while in the background children are building a toy brick tower which collapses, symbolising the inadequately fed body).

Danone's approach to the food market must be seen in relation to the fact mentioned in the introduction, namely that food is deeply anchored in social relations and local contexts.Even Coca-Cola and McDonald's localise their market communication to some 
extent whereas, for example, luxury goods such as perfumes and watches seem to get away with and even capitalise on their global standardisation (Gram 2007). In the field of food, health and anxiety, where Danone operates, the webs of meanings at play are indeed very complex.

The following quantitative and qualitative analyses are carried out to analyse Danone's global market approach regarding health, and for this purpose the Danonino commercials were selected. The sample is a convenience sample provided by Danone, and it consists of commercials from 2001-7, eight Danish, 34 German, 37 French, 30 Spanish, 34 Polish and 32 Russian commercials. The sample is slightly uneven as it was not possible to obtain all commercials from all years, and because Danone has been more active in promoting its products in some markets than in others. The selected countries were chosen as it was deemed relevant to include country samples from various regional areas, Germany and Denmark representing Northern Europe, France and Spain, Southern Europe, Poland and Russia representing newly emerging markets and economies and in diverse developmental stages (mature, growing, emergent). Furthermore the countries were chosen to include various regional areas offering different contexts for child rearing and food intake.

The results represent an example of global food advertising clearly anchored in local contexts. Danone carried out the campaigns in co-operation with local subsidiaries and agencies. Despite its unevenness, the sample seems apt to offer insight into very different approaches to branding of the health message across these European markets.

All commercials were assessed and discussed by at least two researchers, and they were rated on several content variables. The aim of the quantitative analysis is to reduce a large set of commercials to a more manageable and meaningful set in order to gain insight into Danone's communication on food, fun/entertainment and health across different European cultures. As a consequence factor analysis and clustering were used. Since the data collected are nominal, an appropriate data reduction technique is correspondence analysis. A correspondence analysis was run on the following variables: definition of playfulness and general values depicted in the commercial. The ad scores on each factor were saved and the co-ordinates on the factors were used as input variables in a hierarchical clustering procedure. The resulting groups were then described using variables such as product category, gender and ethnic origin of characters, voice-over, eating environment, eating occasion, as well as specific criteria about health content and the relation between food and playfulness.

The qualitative analysis is built up thematically and the literature review functions as a conceptual framework. The data were analysed with an openness towards patterns and tendencies; this offers knowledge about the strategies employed to communicate that the product is healthy for children and anxiety reducing for parents. The authors explored typical national commercials addressing health issues. This was done through a thematic analysis considering both visual and verbal aspects of the commercials.

\section{Quantitative analysis of Danonino campaigns}

Correspondence analysis was run on two descriptive variables of commercial content: definition of playfulness and general value depicted in the commercial. Both variables comprised six categories:

Definition of playfulness:

no playfulness;

play as learning; 
0 play as art and expression of self;

0 play as adventure, sensation seeking, risk taking;

- play as social activity, friendship;

- play as physical activity, sport.

These definitions of play have been synthesised from the seminal work by Sutton-Smith (1997).

General values depicted in the commercial:

fun, play, leisure;

0 escape from reality: imagination, dream, fantasy;

0 independence, adventure, danger, risk taking;

health, vitality, energy;

joy, spirituality, contentment;

0 other.

These values linked to children's activities are described in the work by Kline (1993). Prior to the correspondence analysis, the relationship between the variables was gauged through cross- tabulation. Standard bivariate statistics demonstrated a moderate, but still significant relationship between the variables. ${ }^{4}$

Three axes were retained from the correspondence analysis, accounting for $95 \%$ of total inertia:

- The first axis accounts for $49 \%$ of inertia. It opposes 'Play as adventure, sensation seeking, risk taking' and general value 'independence, adventure, danger, risk taking' to 'fun, play, leisure', 'play as art and expression of self' as well as 'health, vitality, energy' and 'play as physical activity, sport'. It represents a dimension that differentiates commercials describing food as part of an adventure, an experience that stresses independence and risk taking, and commercials presenting food either as providing a physical benefit: health, vitality - or a psychological benefit: fun and sensation.

- The second axis accounts for $33 \%$ of inertia. It opposes 'fun, play, leisure' to 'health, vitality and energy' and 'no playfulness' in the commercial. It differentiates commercials describing food as providing a psychological benefit: fun and sensation, from commercials stressing a physical benefit: health, vitality and energy or no benefit.

- The third axis accounts for $13 \%$ of inertia. It opposes 'play as an art and expression of self', 'imagination, escape, dream, fantasy', 'play as a physical activity' to 'play as a social activity, sport' and 'training, learning'. This dimension is a minor one. It differentiates commercials that present play conceived as an individual activity and an escape from reality from commercials presenting play as a social activity, an activity embedded in real playgrounds and social groups.

The two first dimensions exhibit a significant comparable inertia. They constitute the major dimensions through which playfulness depicted in the commercials can be described. The third dimension appears as a more marginal one. Overall, the 175 Danonino commercials can be reduced in a space encompassing three dimensions.

The ad scores on these three dimensions were used as input variables in a hierarchical clustering procedure using Ward's method. The clustering procedure yields a four-group solution as shown in Figures 1 and 2. The groups were contrasted using descriptive variables such as product category, gender and ethnic origin of characters, voice-over, eating environment, eating occasion, as well as specific criteria related to: 
- Health content: health verbatim; verbatim about well-being; general values depicted in the commercial; value associated to consumption; and

- Relationship between food and playfulness: definition of playfulness in the commercial; playful elements associated with food, eating occasion, or brand and type of playfulness enacted in the commercial.

This description of groups allows us to label them.

- The first group comprises 56 commercials (32\% of the corpus), that is, commercials that do not exhibit any playful element associated with food, with the eating occasion nor with the brand, or any relationship between food and playfulness. Health content is focused on health, energy, vitality regarding general values depicted in the commercial or verbatim about well-being. Health narrative is related to pureness, balance, healthiness and naturalness. The commercials are targeted at mothers and does not show any animated character or brand character. This group of commercials has been labelled 'Utility commercials' as they promote the product on a substantive basis and stress objective health benefits. Fifty-nine per cent of the Russian commercials, 37\% of the Spanish commercials and 29\% of the German/Danish commercials appear in this group. The Russian commercials represent $33 \%$ of the commercials of this cluster.

- The second group comprises 32 commercials (18\% of the corpus). It includes commercials that stress sport and competition, independence, adventure and all forms of play. Play is defined as adventure, sensation seeking, exploration, discovery and risk taking. In the relationship between playfulness and food, the product introduces a playful or fictitious world. The target is the child and the commercial features animated characters and/or brand characters. This group of commercials has been labelled 'Adventure commercials' as they promote food as a way of discovering, of experiencing adventure and sensation. Thirty per cent of the French commercials

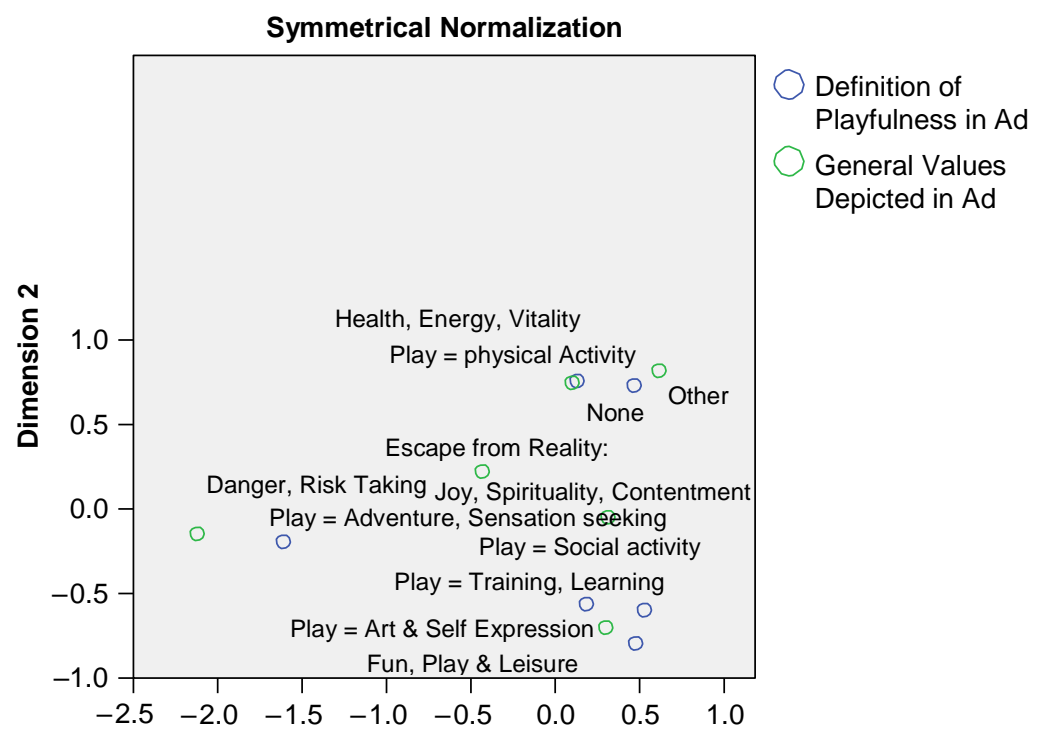

Dimension 1

Figure 1. Projection of row and column points on dimensions 1 and 2. 


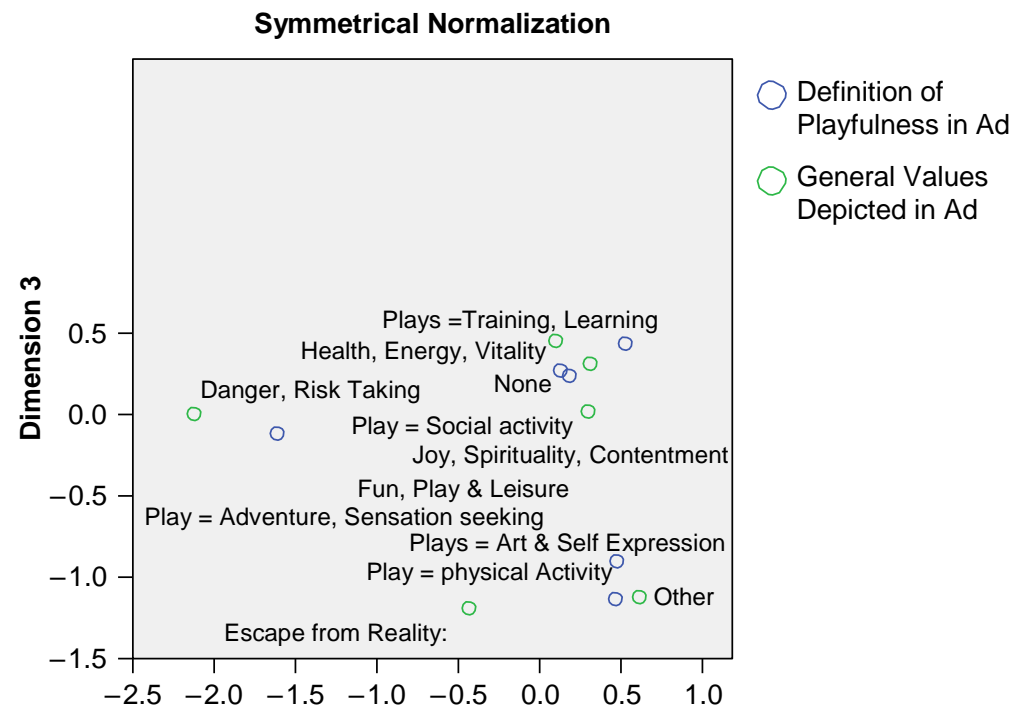

\section{Dimension 1}

Figure 2. Projection of row and column points on dimensions 1 and 3.

and $31 \%$ of the German/Danish commercials appear in this cluster. The German/Danish commercials represent $41 \%$ of this group, and the French ones $34 \%$.

- The third group comprises 55 commercials (31\% of the corpus). These commercials feature promotion techniques such as games, special offers, gifts. Play is defined as training or learning, as art and expression of self or as a social aspect. In the relationship between playfulness and food, the product introduces or opens a playful or fictitious world but as mere entertainment, not as an adventure. No health verbatim is presented. The target is the child. This group has been labelled 'Entertaining commercials'. Forty-four per cent of the Polish commercials and 27\% of the French commercials appear in this group. The Polish commercials represent $27 \%$ of this cluster, and the German/Danish ones $26 \%$.

- The fourth group includes 32 commercials (18\% of the corpus). These commercials stress excitement and happiness. Play is defined as a physical activity, a sport. No relationship is made between playfulness and food. Health verbatim stresses the essential nature of the product. As the target is the mother and the commercials do not feature animated or brand characters, this group has been labelled 'Activity commercials'. Twenty-seven per cent of the French commercials, $27 \%$ of the Spanish and $21 \%$ of the Polish ones appear in this cluster. The French commercials represent $31 \%$ of this group, the Spanish $25 \%$ and the Polish $22 \%$.

Of these four groups of commercials, the first group 'Utility commercials' describing food as a means of supporting the child's physical development and the third one, 'Adventure commercials', where food opens to a virtual world, will undergo further analysis in the next section. Moreover, we will explore which person or character appears to be empowered to talk about health (expert, mother, child, brand character), how healthy eating is communicated and finally what is emphasised as being 'healthy' in the various national contexts. 


\section{Qualitative analysis of archetypal traits of Danonino campaigns}

Danone acts in accordance with the axes identified in the literature study above relating to the dilemma between: (1) fun and nutritious/healthy versus unhealthy food; and (2) healthy food versus food that children like/dislike and the possible ensuing inter-generational conflicts. But also (3) that parents are faced with the dilemma of providing healthy food while at the same time pleasing their children and giving them treats and (4) that parents strive to feel adequate and to counteract anxiety. Danone enters this arena by stating that 'treats can be healthy'. Mothers are shown interacting positively with their children, as opposed to the on-going conflicts, concern and negotiations which are clearly a part of modern families' everyday lives, as shown in the literature study. According to Turner et al. (2006) parents use treats to gain their children's affection and, in the context of Danone, it is argued that here the treat can be given without compromising the child's health - or even to ensure good health. In all country samples growth is visualised as a Superman or Popeye-like transformation - particularly in the commercials directed at children. Nutri-tainment is presented as being the 'fun' product, an 'edible' alternative to traditional healthy food while at the same time health information is being presented in an intelligible and colourful way. This is illustrated in the commercials where parent-child struggles turn into co-operation. Bad feelings against the parent turn into happiness and fondness, and because the child, according to the message of the commercials, is now getting the important nutrients, he or she is bursting with energy and succeeds in school.

Several Danonino commercials or parts of them, films, informational sequences, themes, cartoons, are used more or less identically in several national contexts. The same brand character, Danonino, the blue-and-green cartoon dragon, is used in all national contexts, but not in all types of commercials. This brand character is meant to appeal to a child's universe. Apart from the brand character, some of the commercials are used in more or less identical versions in several markets (such as films with pedagogic, animated sequences inserted in different commercials showing how calcium, protein and vitamins stimulate body growth).

\section{Utility commercials}

In the 'Utility commercials' the role of nutrition and health is most predominant. Food is conceived of as a utility that fuels the development of children; commercials are targeted at mothers (see Table 1). The commercials in the 'Utility commercial' group can be split into four main types of scenarios, which are not all present in all markets:

- Expert explaining the need for the product, usually with children more or less involved in the commercial in some way illustrating the points.

- Mothers expressing relief for having found a satisfying solution (the product) to assure their child's healthy eating.

- Dialogue commercials with children explaining to mothers or audiences why the product is good for children (German commercials only).

- Extended family situations including grandparents (Russian commercials only).

An example of a utility commercial is the German commercial Cat from 2003. In a 'before' situation, a girl is seen pushing away fruit and milk, a boy is seen giving his milk to the cat under the table. In the 'now' situation the boy is eating a Danonino yoghurt. While he is eating his mother explains why the product is healthy. A cartoon is then shown illustrating how vitamins, proteins and calcium build up children's bodies. 


\section{Cartoon character workers with construction helmets and wheelbarrows help the body, depicted as}

Table 1. Description of clusters.

\begin{tabular}{|c|c|c|c|c|}
\hline & $\begin{array}{l}\text { Cluster } 1 \\
\text { Utility commercials }\end{array}$ & $\begin{array}{l}\text { Cluster } 2 \\
\text { Adventure commercials }\end{array}$ & $\begin{array}{l}\text { Cluster } 3 \\
\text { Entertaining commercials }\end{array}$ & $\begin{array}{l}\text { Cluster } 4 \\
\text { Activity commercials }\end{array}$ \\
\hline $\begin{array}{l}\text { Elements associated with food, } \\
\text { occasion to eat or brand }\end{array}$ & No association: $43 \%$ & $\begin{array}{l}\text { Sport, competition: } 19 \% \\
\text { Exploration, discovery: } 25 \% \\
\text { Plays: } 25 \%\end{array}$ & $\begin{array}{l}\text { Promotion, games, special offers } \\
\text { gifts: } 44 \%\end{array}$ & $\begin{array}{l}\text { Excitement, happi- } \\
\text { ness: } 38 \%\end{array}$ \\
\hline $\begin{array}{l}\text { Definition of playfulness in the } \\
\text { commercial }\end{array}$ & $\begin{array}{l}\text { No definition of playful- } \\
\text { ness: } 79 \%\end{array}$ & $\begin{array}{l}\text { Play as adventure, sensation see- } \\
\text { king, risk taking: } 84 \%\end{array}$ & $\begin{array}{l}\text { Play as training, learning: } 40 \% \\
\text { Play as art, expression of self: } 22 \% \\
\text { Play as social aspect: } 38 \%\end{array}$ & $\begin{array}{l}\text { Play as physical } \\
\text { activity, sport: } 47 \%\end{array}$ \\
\hline $\begin{array}{l}\text { Type of relation between food } \\
\text { and playfulness }\end{array}$ & $\begin{array}{l}\text { No relation between play- } \\
\text { fulness and food: } 48 \%\end{array}$ & $\begin{array}{l}\text { Product introduces, opens a play- } \\
\text { ful or fictitious universe: } 44 \% \\
\text { Complementarity between play } \\
\text { and food: } 44 \%\end{array}$ & $\begin{array}{l}\text { Product introduces, opens a play- } \\
\text { ful or fictitious universe: } 40 \%\end{array}$ & - \\
\hline $\begin{array}{l}\text { Values associated to } \\
\text { consumption }\end{array}$ & $\begin{array}{l}\text { Energy: } 34 \% \\
\text { Health, well-being: } 16 \%\end{array}$ & $\begin{array}{l}\text { Pleasure, escape: } 25 \% \\
\text { Magical transformation: } 16 \% \\
\text { Health, well-being: } 19 \%\end{array}$ & Entertainment: $60 \%$ & $\begin{array}{l}\text { Energy: } 28 \% \\
\text { Pleasure: } 28 \%\end{array}$ \\
\hline General values & $\begin{array}{l}\text { Health, vitality, energy: } \\
71 \%\end{array}$ & $\begin{array}{l}\text { Independence, adventure, danger, } \\
\text { risk taking: } 50 \%\end{array}$ & Fun, play and leisure time: $86 \%$ & $\begin{array}{l}\text { Imagine, escape, } \\
\text { dream, fantasy: } 25 \% \\
\text { Other: } 44 \%\end{array}$ \\
\hline Verbatim about well-being & $\begin{array}{l}\text { Energy: } 39 \% \\
\text { Other: } 25 \%\end{array}$ & $\begin{array}{l}\text { Energy: } 38 \% \\
\text { No verbatim about well-being: } 41 \%\end{array}$ & $\begin{array}{l}\text { Evasion: } 16 \% \\
\text { Fun, amusing: } 25 \%\end{array}$ & New: $22 \%$ \\
\hline Health verbatim & $\begin{array}{l}\text { Pure, balanced, sane, } \\
\text { natural: } 5 \%\end{array}$ & $\begin{array}{l}\text { Essential: } 38 \% \\
\text { No health verbatim: } 59 \%\end{array}$ & No health verbatim: $82 \%$ & $\begin{array}{l}\text { Essential: } 41 \% \\
\text { No health verbatim: } \\
44 \%\end{array}$ \\
\hline Eating occasion & Snacking domestic: $59 \%$ & Snacking non-domestic: $28 \%$ & Snacking domestic: $62 \%$ & $\begin{array}{l}\text { Snacking non- } \\
\text { domestic: } 38 \%\end{array}$ \\
\hline Target & Mother: $71 \%$ & Child: $78 \%$ & Child: $67 \%$ & Mother: $56 \%$ \\
\hline $\begin{array}{l}\text { Animated character, fictitious } \\
\text { universe }\end{array}$ & No: $64 \%$ & Yes: $72 \%$ & Yes: $73 \%$ & No: $59 \%$ \\
\hline
\end{tabular}


Table 1 - continued

\begin{tabular}{|c|c|c|c|c|}
\hline & $\begin{array}{l}\text { Cluster } 1 \\
\text { Utility commercials }\end{array}$ & $\begin{array}{l}\text { Cluster } 2 \\
\text { Adventure commercials }\end{array}$ & $\begin{array}{l}\text { Cluster } 3 \\
\text { Entertaining commercials }\end{array}$ & $\begin{array}{l}\text { Cluster } 4 \\
\text { Activity commercials }\end{array}$ \\
\hline Brand character & No: $52 \%$ & Yes: $75 \%$ & Yes: $82 \%$ & No: $53 \%$ \\
\hline Voice-over & Male adult: $48 \%$ & - & $\begin{array}{l}\text { None: } 46 \% \\
\text { Other: } 26 \%\end{array}$ & Male adult: $44 \%$ \\
\hline \multirow[t]{2}{*}{ Country } & Russia: $33 \%$ & $\begin{array}{l}\text { France: } 34 \% \\
\text { Germany, Denmark: } 41 \%\end{array}$ & Poland: $27 \%$ & Spain: $25 \%$ \\
\hline & 56 ads $1 / 4 \quad 32 \%$ & 32 ads $1 / 4 \quad 18 \%$ & 55 ads $1 / 4 \quad 31 \%$ & 32 ads $1 / 4 \quad 18 \%$ \\
\hline
\end{tabular}


a machine, function, and the functionality of the elements of the Danonino product is shown: vitamins (showing metabolism, making the (body) machine work), proteins (showing growth of muscles) and calcium (illustrating construction of bones). The mother hugs her child while he still eats enthusiastically. It is stated that this is milk but in a different form. The commercial ends with a small scene where the cat is pushed away by the child who now wants the healthy food for himself. A final image illustrates that these yoghurts are without additives and without artificial flavours.

In the commercial it is said that this product is 'Exactly to their taste', thus pointing to the parents' difficulties when dealing with choosy children. Furthermore the dilemma of healthy/unhealthy food, good/bad food is addressed in the statement: 'Good things can be healthy', summing up the inherent assumption that good food in the eyes of children equals food with low nutritional value. The explicit presentation of the child in this commercial is someone who either blankly refuses to eat fruit and drink milk or cheats by giving the milk to the cat (an irrational 'human becoming' not to be counted on). In the commercial the solution lies in the parent offering an alternative which is said to combine health concerns and the child's preference (both of the food item and the parent). In the commercial's scenario, conflict is avoided and health is not compromised. This is thus presented as a situation where Danone claims to be offering 'a third way' - with what they present as nutritious and fun food. This theme is presented in various ways in several national contexts. The above commercial is an explicit example of nutri-tainment. The health implications of vitamins, proteins and calcium are pedagogically presented in an entertaining way.

In all national samples (except the Danish) health is addressed systematically in the 'Utility commercials'. However, the health discourse is staged with differing patterns in each national setting. Health issues are articulated by the following:

the expert (doctor, paediatrician, nutritionist, dentist);

the mother;

0 the brand character Danonino;

0 the child (Germany only);

0 health institutions (Poland).

For instance, in the Russian commercials the mother is used to articulate concerns for her child's health, an example being a commercial where a mother is at infant school with her son and she says:

I have been told that in our country, half of the population of children are lacking in calcium and iodine. Then I started to worry. 'What do I do if my child lacks calcium too?' It seems like everything is fine, but maybe this is not how it really is; it is difficult to verify. It is important not to ruin anything from the start in childhood where everything is in the process of construction. When we learnt that Danonino is rich in micro-elements, we started to buy it more often. It is not a panacea, but it gives to us mothers a certain sense of self-assurance. Children quickly understand that they need iodine and calcium. Now Lesha [son] eats Danone's little yoghurts every day and I am happy (Russian commercial 2007).

This statement by the Russian mother in the 2007 commercial is adapted to the Russian market. The mother refers to information about special nutrient needs of Russian children (the emphasis on iodine is unique for the Russian market, in the other national samples the focus is on vitamins, calcium and proteins). The mother bonds with mothers in general 'we mothers' and talks about the lack of self-confidence and fear of ruining the child's potential by feeding him/her insufficiently. The mother stresses that she cannot be certain that her son gets all he needs, even if he apparently is doing well. It is the only context where the daily consumption is mentioned and linked directly to the mother's happiness. 
In a utilitarian perspective, the expert is used in several contexts, from the more 'soft' experts, who could be a mother (e.g. the German sample) to 'hard' experts in white coats, such as doctors (France) or dentists (Poland). In the Polish context the Mother and Child Institute is used as an authority of approval. It is said in one Polish commercial: 'Danonki: The Mother and Child Institute confirms that two-thirds of children get too little calcium. Danonki is recommended by the Mother and Child Institute.'

\section{Adventure commercials}

The French commercial La patinoire (2003) exemplifies the distinctive characteristics of the 'Adventure commercials' group. In the French context the yoghurts are called 'little pots of strong bones'. This commercial also plays on the insecurity of parents. In this case, the issue is not the lack of knowledge about what happens inside the child's body, but what might happen when the child is out of sight: 'We cannot always monitor [our children] but we do our best to prepare them for when we cannot be there' (voice-over in French commercial 2003). This can be interpreted as an attempt to relieve parents of guilt and fear, but still stressing their parental responsibility. French parents spend much time away from their children as opposed to German families where there are many non-working mothers. This can therefore also be considered as a culturally adapted commercial.

This group of commercials also emphasises the role of the mother as a central figure in many countries, except in the Danish ones where she does not appear at all. In the German context, she is mostly seen as the background person or helper, and she only makes few appearances in the French commercials, which may be linked to the fact that France has a very large number of working mothers.

Another example of the adventurous universe is the commercial Danonino and the Dragon which is used in several national contexts; it shows how the product virtually makes children grow making them strong enough to fight a dragon. This is like a 'Popeye effect' where spinach gives him supernatural powers, a typical superhero theme. ${ }^{5}$ As shown in the quantitative analysis, in commercials directed at children there is hardly any talk about health concerns, but growth and strength are visualised.

\section{Atypical cases}

The Danish commercials do not include the health aspect at all. In the 1990s dentists and other health workers launched a campaign against Danone's yoghurts in Denmark due to the high sugar content of the yoghurts. For this reason Danone has had a poor image in the eyes of the adult population in Denmark, which is probably why commercials were not targeted directly at adults. It can be considered a cultural adaptation that the appeal to the mother and the focus on health are omitted from the Danish commercials. The Danish commercials are almost exclusively directed at children by means of a cartoon or adventure universe, through co-branding efforts by showing extracts of children's movies from which they get stickers or tattoos along with other gifts when buying the products. In the German sample, children are empowered to articulate the health discourse. For instance, in the commercial Children's Theatre (2006), a boy says: 'Dear parents' standing in what could be a school play holding yoghurts explaining that they contain milk (enter two children dressed up as a cow) and that they contain fruit and no refined sugar (illustrated by two children dressed as strawberries and grapes, kicking away lumps of sugar). Finally they all eat and enjoy the yoghurts. A stamp across the screen says that 
the product contains no refined sugar, but the taste is the same (as with refined sugar).This role distribution is seen in several German commercials where children explain the health message to parents or other children. This can be linked to the fact that independent and autonomous children are a very important ideal for upbringing in Germany (Malpas and Lambert 1993). This is the only national setting where children enter this active role of health communicators (as agents and rational human beings rather than objects or human becomings in Qvortrup's (1987) terms.

\section{Visual rhetoric about health}

Direct health communication includes factual information about ingredients, healthy feeding as a duty and concern of mothers and also prevention against the child's insecurity and anxieties. Beyond these elements, visual rhetoric about health allows indirect communication, for instance when the product is shown in proximity to fruit or milk, when it is associated with children's energy levels or children's learning capacities, and even in some cases, visually enacted as stimulating physical and intellectual development. Especially in the German context, there is a very strong focus on 'without refined sugar' which fits well with the study mentioned above stressing German parents' interest in non-industrial and organic food - pure food. In the German sample, health is very strongly communicated through the pureness of the product which consists of nothing but fruit and milk, and with no additives. Images of fresh fruit and quality stamps are used widely.

Some of the localised Danone commercials indicate what happens if the child does not get the recommended nutrition. In a Spanish commercial, for example, a nutritionist talks about the importance of building up a strong body. In the background two children are building a Lego tower. The tower collapses symbolising a fragile body with bones that have been lacking calcium. The Lego bricks are children's objects, a visual rhetoric symbolising the child collapsing. In another context (French), a doctor in a white coat illustrates, with the use of model bones, how a bone lacking in calcium is much more fragile. The same theme is used in the Russian sample where there is a strong focus on the strength of bones and the body. The unhealthy body and fragile bones lacking in calcium are symbolised by bricks or pillows collapsing, as opposed to being well built (e.g. correctly constructed Lego towers), resisting pressure. Lack of energy - caused by the want of the right nutritional elements - is also used in a number of German commercials where children are trying to do homework: they find it hard to concentrate on their math assignments, and they are de-motivated. The commercial is in black and white until Danonino enters the scene leading the children to the refrigerator to get Danone products, and suddenly the colours are back and the children are happy and energised.

German mothers appear in several commercials, either in the background as helpers or in interaction with children. German mothers are to a large extent around their children, with a high percentage of non-working mothers or mothers working part-time, which might explain why they are so visible in the commercials. Danish and French mothers typically work outside the home. In the Danish commercials, there is absolutely no sign of mothers, in the French commercials they are absent with a few exceptions. In the Spanish, Polish and Russian commercials, mothers are very visible, in several cases giving testimonials recommending regular or daily use of Danone's products, and in other situations as helpers (serving the product to the hungry, thirsty or tired child), or in interaction with children, or as observers of the playing or sleeping child. Experts are used especially in France, Poland, Russia and Spain, whereas only in the German sample children articulate the health message. 


\section{Discussion}

In several of the commercials the child is presented as the human becoming (in Qvortrup's terms), for example in the German commercial Cat presented above, where the child is seen as an irrational being counteracting the rationality and necessity of healthy eating. This holds true in several of the other parent-directed commercials from the French, Polish, Russian and Spanish settings where the child is presented as an object - albeit precious - typically playing in the background, irresponsible and vulnerable, totally dependent on the actions and care of the parent and on expert advice. A different scenario is presented in the German commercial Children's Theatre, also presented above, where the child articulates what healthy eating is. Here the child is seen as a - albeit small, cute and with a speech impediment - rational agent who is empowered to take responsibility. This reflects a development over time in the German commercials, which matches the ideals of autonomy and independence of German ideals for upbringing. In Danone's commercials directed at children, which have not been treated in-depth in this article, the cartoons and storytelling techniques are applied. These commercials also appeal to the child as an actor longing to be entertained and have an eventful existence.

The four central axes identified in the literature study were: (1) the dichotomy of healthy versus unhealthy; (2) whether the children like the food or not and do they eat what the parent serves; (3) whether the child likes/dislikes his or her parents (reflecting parents' desire to be loved by the child); and finally (4) whether or not the parent feels safe and adequate or guilty and worried. The study of the Danonino commercials show that Danone taps into these axes by: (1) suggesting a third way offering an allegedly healthy product tasting just as good as an unhealthy one; (2) ensuring that the child eats; and (3) that the child loves his or her parents; and finally (4) reassuring the parents to feel safe and adequate.

\section{Conclusion}

The aim of this article was to explore how the communication between Danone and its global markets is handled, knowing that issues of food, especially food for children, are deeply anchored in cultural contexts. The article's special focus was to examine how Danone combines the health discourse and the entertainment aspects when promoting their products to parents and children across cultures.

It can be concluded that Danone takes an adaptive approach to the six markets examined in this study. The commercials were developed in close co-operation with local subsidiaries, based on local knowledge; the commercials reflect differing local realities requiring both a localised approach content-wise and communication-wise.

The health-related messages appear in two groups of commercials: utility commercials, where food is presented as fuel for the child's healthy development, and adventure commercials, where food opens up to a virtual world and where the products offer the necessary strength for overcoming challenges.

The role of children in the commercials differs: in some of the German commercials, children are the ones who explain the qualities related to the products' health value (portrayed as active agents), whereas they act as background figures (vulnerable objects) in several other national samples and in the early German commercials, except in the commercials directed specifically at children in all national contexts where children have 
leading roles with the brand character Danonino (agents).

This article is mainly empirical, but its theoretical contribution is an exemplification of how theory of perceptions of childhood can be used to analyse contemporary commercials directed at parents and children. Furthermore the article offers a clarification of the various axes of power and meaning that are at play regarding health, food and market communication in the relationship between parents, children and the market.

In the axes described in the quantitative analysis, there is a clear dichotomy in the commercials between what is said to be healthy versus unhealthy even though, as demonstrated, slight variations appear in what is emphasised as healthy. In all country samples the product is clearly branded as fun and tasty food, and the child/parent relationship is central in all country samples (except the Danish sample), where the parent appears concerned and worries whether the child is really getting what he or she needs (before the parent identified the product promoted). The child is shown as grateful and energised when allowed to have the product, a child who does well in school, sports and play.

Furthermore the message related to health is articulated in different ways in the various national contexts. Whereas the subject of health is avoided in the Danish context, the communication strategy on the German market is primarily informational and emotional, whereas on the French, Spanish, Polish and Russian markets the tone is more directive, appealing more to guilt and duty, and more explicitly sketching the consequences of not ensuring the correct nutrition for children.

Danonino combines the health discourse and the entertainment aspects when promoting their products to parents and children across cultures. This is done in several ways: indirectly by the use of toy brick and pillow towers to symbolise the stability of bones, and by showing children with no energy. The most pronounced way nutri-tainment is used is in a small cartoon movie which is used as an insert in several markets, and in a visualisation of how proteins, vitamins and calcium stimulate growth in the body. This is an attempt, in a playful and intelligible way, to explain why these elements are so important and to link this understanding to Danone's products. Health being linked to the intake of calcium is commented on in all contexts (except the Danish). In Germany especially the message that the product is made without refined sugar and additives, and is therefore 'natural', is promoted. The product is often shown in relation to fresh fruit and milk. In France, a strong emphasis is seen on growth, and in this process calcium and vitamins are presented as vital. The 'without sugar and additives' message seems less prominent. In Russia, there is a strong emphasis on calcium and iodine and the 'no refined sugar' message is not particularly prominent.

Other differences can be seen which relate to gender roles, particularly with regard to the role of mothers. The German mother is particularly prominent as a background figure in the child's environment, especially in the kitchen. In contrast, French mothers are primarily shown as working outside the home. Spanish, Russian and Polish mothers make testimonials in several commercials.

Experts are used explicitly in the Russian, Polish and French markets where, rather more traditionally, their white coats suggest authority to create trust and persuasion. Furthermore the organisation, the Mother and Child Institute, is used as guarantor for the quality of the product in Poland. In Germany, the quality stamp is used extensively.

All in all it is evident that Danone has used a differentiated approach to its global 
markets throughout the Danonino advertising campaign, and that the nutri-tainment message has been presented in a variety of ways by different 'spokesmen' across markets.

It seems clear that Danone has considerable insight in its local markets, and it is reflected that the commercials are localised or even developed to match the local contexts. As an avenue for future research it would be very interesting to do reception analyses of these commercials to assess how they are received in the local markets (also to see differences in reception of commercials developed over a standardised model versus commercials developed specifically to local contexts). Obviously the analysis in this article could furthermore gain by being supplemented with more in-depth research on local value priorities, perceptions of healthy vs unhealthy foods, gender roles and so on to arrive at a more comprehensive understanding of how good the fit between message and culture actually is.

\section{Notes}

1. Website: http://www.Danone.com (version of the 14 November 2008).

2. Economic and Social Report 2006, page 23.

3. Website: http://www.Danone.com. See 'Some of our brand stories around the world' November 2008.

4. (Chi square $1 / 489.955,25$ d.f., $p, .000$; Contingency Coefficient C $1 / 4.583, p, .000$; Cramer's $\mathrm{V} 1 / 4.321, p, .000)$.

5. As this paper analyses commercials from 2001-7, it must be added that, as a consequence of objections raised by consumer associations, Danone decided to move away from this kind of message which implies a direct link between the product and children's growth.

\section{Notes on contributors}

Malene Gram, MA, PhD, is associate professor at Aalborg University, Denmark. She has worked extensively with cross-cultural studies, with a special emphasis on children and family issues, consumer behaviour and tourism. She has published in Childhood, Young Consumers, Journal of Consumer Culture and Journal of Marketing Communications.

Valérie-Inés de la Ville is professor at the University of Clermont (France). She is the founder of The European Centre for Children's Products, a training and research unit focused on children-orientated markets. Her research interests are in new perspectives in consumer socialisation, innovations in children-orientated markets as well as in the ethical issues raised by addressing children as consumers. She supervises a French interdisciplinary research programme on Children and Fun foods.

André Le Roux, $\mathrm{PhD}$, is associate professor of marketing at the Business Administration Department of the University of Poitiers (France). Before joining the academic circles, he had a career in marketing surveys and consultancy. His current research interests include consumer behaviour and marketing research.

Nathalie Boireau, PhD, Consumer Science Danone Research, is responsible for the department of Kids Science at Danone Research Center (Palaiseau, France).

Olivier Rampnoux is associate professor at the European Centre for Children's Products (CEPE) of the Business Administration Department at the University of Poitiers (France). His areas of research are around child marketing and corporate application like serious game or social network services.

\section{References}

Atkins, P., and I. Bowler. 2001. Food in society: Economy, culture, geography. London: Arnold. Caplan, P. 2002. Food, health and identity. London: Routledge.

Cook, D.T. 2007. Semantic provisioning of children's food: Commerce, care and maternal practice.

Unpublished work paper. 
Douglas, M. 1984. Food in the social order. New York: Russell Sage Foundation.

Featherstone, M. 1995. Undoing culture: Globalization, postmodernism and identity. London: Sage. Fischler, C. 1988. Cuisines and food selection. In Food acceptability, ed. D.H. Thomson. London: Elsevier Science.

Fuat Firat, A., and A. Venkatesh. 1995. Liberatory postmodernism and the reenchantment of consumption. Journal of Consumer Research 22: 239-67.

Gram, M. 2007. Whiteness and western values in global advertisements: An explorative study. Journal of Marketing Communications 13, no. 4: 291-309.

Hastings, G., M. Stead, L. McDermott, A. Forsyth, A. MacKintosh, M. Rayner, C. Godfrey, M. Caraher, and K. Angus. 2003. Review of research on the effects of food promotion to children. Glasgow: Centre for Social Marketing, University of Strathclyde.

James, A. 1982. Confections, concoctions, and conceptions. In Popular culture: Past and present, ed. B. Waites, T. Bennett, and G. Martin, 83-95. London: Open University Press.

Kline, S. 1993. Out of the garden: Children's culture in the age of advertising. Toronto: Garamond.

Malpas, N., and P.Y. Lambert. 1993. The Europeans and their family. Brussels: Commission of the European Communities, Eurobarometer 39.

Qvortrup, J. 1987. The sociology of childhood: Introduction. International Journal of Sociology 17, no. 3: 3-37.

Rudawska, I. 2001. New trends in food consumption in Poland versus western countries. British Food Journal 103, no. 7: 495-500.

Russell, C.G., and A. Worsley. 2007. Do children's food preferences align with dietary recommendations? Public Health Nutrition 10, no. 7: 1223-33.

Seiter, E. 1993. Sold separately: Children and parents in consumer culture. New Brunswick: Rutgers University Press.

Solomon, M.R. 1996. Consumer behavior. 3rd ed. London: Prentice-Hall International Editions.

Sutton-Smith, B. 1997. The ambiguity of play. London: Harvard University Press.

Synnott, K., J. Bogue, C.A. Edwards, J.A. Scott, S. Higgins, E. Norin, D. Frias, S. Amarri, and R. Adam. 2007. Parental perceptions of feeding practices in five European countries: An exploratory study. European Journal of Clinical Nutrition 61: 946-56.

Turner, J.J., K. James, and K. McKenna. 2006. Food for thought: Parents' perspectives of child influence. British Food Journal 108, no. 3: 181-91.

Warde, A. 1997. Consumption, food and taste. London: Sage. 